\author{
Associate Professor Gina Cristina DIMIAN, PhD \\ E-mail: gina.dimian@csie.ase.ro \\ Professor Erika MARIN, PhD \\ E-mail: erika.marin@csie.ase.ro \\ Department of Statistics and Econometrics \\ The Bucharest University of Economic Studies \\ Professor Eng. Josef JABLONSKY, CSc \\ Department of Econometrics \\ The University of Economics Prague \\ E-mail: jablon@vse.cz
}

\title{
INVESTIGATING THE LONG AND SHORT-RUN SALARY- EMPLOYMENT RELATIONSHIP IN ROMANIA: A SECTORIAL APPROACH USING THE ARDL MODEL
}

\begin{abstract}
The paper aims to investigate the relationship between real salary earnings and employment from a sectorial perspective. This research topic has been of great interest for scientists over time, but the results of the empirical studies have been rather conflicting. Moreover, the subject is important considering that can be a source of guidance for the strategies aimed at increasing employment through wage measures. The paper objective is twofold: studying employment and real salary earnings evolution and assessing the existence and direction of this relationship in a dynamic panel framework. To achieve the main goal of the research ARDL model has been preferred due to the fact that it allows quantifying both long and short-term relationships. Econometric analysis outcomes suggest the existence of a direct relationship between real salary earnings and employment on the long-term and a negative relation on short-run. The results for the economic sectors of activity are more varied.
\end{abstract}

Key-words: total employment, real salary earnings, panel data, ARDL model, Romanian activity sectors.

JEL Classification: C23, E24, J21, J31

DOI: $10.24818 / 18423264 / 53.1 .19 .01$ 
Gina Cristina Dimian, Erika Marin, Josef Jablonsky

\section{Introduction}

Investigating the relationship real salary earnings-employment represented a challenge for scientists in the past (Geary and Kennan, 1982, Mehra, 1982, Nickell and Symons, 1990, Pehkonen, 1991) and continues to be of interest nowadays (Suedekum and Blien, 2004, Arpegis and Theodosiou, 2008, Dias Marques and Martins, 2013, Bakker, 2015, to name but a few of the researchers in the field), taking into consideration the fact that, so far, research findings are still contradictory. All the various opinions, starting with classical theory, have tried to explain this relationship while empirical studies have tested the validity of the theory.

A comprehensive description of the ideas developed on this issue and the results of some empirical studies can be found in Arpegis and Theodosiou (2008): $a$. Classical and neo-classical economic theories claim, based on the self-correcting market mechanisms, that a negative close relationship exists between real wages and employment levels, which means that employment growth and unemployment decrease could be achieved by reducing wages; $b$. Keynes theory argues that cutting wages would keep production and employment unchanged because it will lead to a chain effects, reducing the demand for goods and, therefore, the need for labour force; c. Purchasing power argument (PPA): points to a significant positive relationship between real wages and employment growth rate due to the wage effect on demand; $d$. Empirical studies: have demonstrated the existence rather of a negative relationship between real wages and employment level or employment rate, and, in some cases, even close to zero correlation, although the authors of recent studies do not exclude the possibility for different type of relationships, even positive, determined by the specific conditions of each country.

Nickell and Symons (1990) proved that detecting the correct direction of the relationship real wages - employment depends on the deflator selection and on using flexible trends. On this basis, the authors have demonstrated the existence of a significant and stable over time negative relationship. Using advanced econometric techniques (Granger Causality Test and Vector Autoregressive Technique), Pehkonen (1991) confirmed the impact of wages on employment, but highlighted the problems that occur when the relationship needs to be further analysed.

By appealing to the same type of methods, Arpegis and Theodosiou (2008) demonstrated that in the context of a panel data, collected from a total of 10 countries for the period 1950-2005, the direction of the influence is moreover from wages to employment. Basically, employment growth driven by an increase in demand is what leads to diminishing wages. In this regard, the paper Stimulating employment growth with higher wages? A new approach to addressing an old controversy of the same authors (Suedekum and Blien, 2007) demonstrates that in Western Germany the 
Investigating the Long and Short-Run Salary- Employment Relationship in Romania: A Sectorial Approach Using the ARDL Model

relation between neutralized regional wages and employment growth is significantly negative. Thus, at least in Western Germany's case, there are no arguments to confirm the PPA or the fact that rising wages can lead to employment growth, but rather to claim that demand side effects of wages on employment growth only play a moderation role.

Seeking to find out the role played by wages in the Great Depression, Bakker (2015) proved the fact that their lack of flexibility made some countries to have serious problems with unemployment. In Spain, for example, two-thirds of the employment losses can be attributed to reduced wage flexibility. In the same sense, Zaman and Goschin (2014) have demonstrated, using data from the Romanian counties that, during crises and in close proximity, there is an increase tendency of divergence in terms of wages, noteworthy being the fact that county unemployment rates do not seem to have a significant influence on wages growth due to low spatial flexibility.

In conclusion, scientists have examined the causal relationship between wages and employment and the results of the empirical studies have been contradictory. Most often, a negative relationship between the two variables has been detected, but other possibilities cannot be ruled out: an insignificant or even a positive relationship. These results, rather conflicting, can be attributed to several factors. They depend on the specific conditions in which markets operate, the accuracy of data used, the statistical methods selected and the time frames analysed.

In this context, our paper aims to study the link between real salary earnings and employment in Romania, from a sectoral perspective, in the period 1995 and 2016. This relationship has a strong country-specific character, as the most recent studies in the field demonstrate (Christl, Köppl-Turyna and Kucsera, 2017) and we expect to have a sector-specific character also. Analysing the relationship between the two variables is interesting not only by the fact that the results of the empirical studies for various countries have been discrepant, but also in practical terms, of the possibility to guide the strategies focused on stimulating employment through wage measures. The subject is even more important nowadays, when after the recent crisis, Romanian as other European Union countries, is facing significant financial, social and demographic problems (Minjina, 2010, Triandafil et al. 2011, Suciu and Florea, 2018) and now, more than ever, governments can set as major objectives achieving higher rates of employment or even full employment (Parguez, 2008).

Our contribution to the literature is the following: a) first we assess the relationship between the two above mentioned factors in Romania which is an interesting case, a developing country, having for a long period of time low wages among competitiveness factors to attract foreign investments; b) we extend the 
Gina Cristina Dimian, Erika Marin, Josef Jablonsky

investigation by including in the analysis 14 economic sectors of activity with a view to capture differences between them; c) we use Autoregressive Distributed Lag (ARDL) technique for the sake of examining salary earnings-employment relationship both on long and short-term.

The paper objective is twofold: evaluating employment and real salary earnings evolution and establishing the existence and direction of the relationship. Applying ARDL technique gives greater accuracy of the results, taking into account the advantage to study both long and short-term relation. The rest of our paper is organised as follows: Section 2 presents the data and methodology; Section 3 discusses the results of the applied methodology; Section 4 focuses on the main conclusions.

\section{Data and Methodology}

The main two goals of the empirical analysis are:

A. the investigation of the employment and salary earnings evolution, with emphasis on the sectorial differences (descriptive statistics).

B. the study of the long and short-term relation between the two variables, the existence and direction of this relationship (econometric analysis).

The variables considered are: total employment (domestic concept) and the average net real monthly salary earnings. Data were taken from EUROSTAT (employment) and National Institute of Statistics (salary earnings), covers the period 1995-2016 and refers to 14 economic sectors: Agriculture, forestry and fishing (AGR), Mining and quarrying (MIN), Manufacturing (MAN), Electricity, gas, steam and air conditioning supply (ELEC), Construction (CONS), Wholesale and retail trade; repair of motor vehicles and motorcycles (TRADE), Accommodation and food service activities (ACCOM), Transport and storage (TRANS), Information and communication (INFO), Financial and insurance activities (FIN), Real estate (REAL), Public administration and defence; compulsory social security (ADM), Education (EDU), Human health and social work activities (HEALTH).

Professional, scientific and technical activities and Administrative support service activities, from the Classification of Activities in the National Economy (CANE Rev. 2, Harmonized with European classification in the field (NACE Rev. 2) have been excluded from the analysis because they do not have direct correspondence with the previous classification system CANE Rev. 1, employed until the year 2008.

The data for the total employment (domestic concept) (EMPL) are expressed in thousands of people, and those for the average net real monthly salary earnings $(S A L)$ in RON, prices of the most recent year, 2016. In the regression analysis, the 
Investigating the Long and Short-Run Salary- Employment Relationship in Romania: A Sectorial Approach Using the ARDL Model

variables have been used in logs. Sectorial gross value added variable (GVA) has been used in the regression analysis in order to capture business cycle dynamic.

Achieving the second objective of the paper has involved several steps:

B1. Structural break and integration analysis of the time series

B2. Panel Integration Analysis

B3. Panel Causality (Toda-Yamamoto procedure and ARDL model)

B1. The presence of a structural break in our time series has been tested using the CUSUM of Squares Test. We have followed the following steps:

- $\quad$ regressing each variable only on intercept and trend using OLS, like:

$y_{t}=a+b \cdot t+u_{t}$,

- applying CUSUM of Squares tests in Eviews in order to obtain the estimated break dates.

The procedure has been applied for all the 3 variables and 14 activity sectors and the most important outcomes have been detailed in the subsequent part of the paper.

The results of the structural break analysis have been then used in the integration analysis where we have applied Vogelsang (1993) tests.

B2. The null hypothesis of non-stationarity of the variables in the panel data framework can be verified using specific panel data ADF statistics. For the first variable (total employment), as an example, we tested the existence of a unit root using the following equation (Ferda Yerdelen Tatoğlu, 2011):

$$
\Delta e m p l_{i t}=\alpha_{0 i}+\alpha_{1 i} e^{e m p l} l_{i t-1}+\alpha_{2 i} t+\sum_{j=1}^{m l a g_{i}} \beta_{i j} \Delta e m p l_{i t-j}+\varepsilon_{i t},
$$

where empl $_{i t}$ refers to total employment (in logs) in sector $i=1,2, \ldots ., N$ at time $t=1,2, \ldots, T$. The lag length of the difference terms (mlag) can be selected using different criterions, for example Akaike Information Criterion (AIC), or SIC (Schwarz Information Criterion). The Hadri Z-stat is based on the null hypothesis that the series is stationary: $H_{0}: \alpha_{1 i}<0$, for all $i$, the rest of the tests relies on the null hypothesis of non-stationarity: $H_{0}: \alpha_{1 i}=0$, for all $i$.

B3. Granger causality analysis can be applied on non-stationary data by the instrumentally of Toda-Yamamoto procedure. This procedure implied the following steps:

- $\quad$ estimating a VAR model like: 
Gina Cristina Dimian, Erika Marin, Josef Jablonsky

$$
\begin{aligned}
& \operatorname{sal}_{i t}=a_{0}+a_{1} s a l_{i, t-1}+\ldots+a_{p} s a l_{i, t-p}+b_{1} e m p l_{i, t-1}+\ldots+b_{p} e m p l_{i, t-p}+e_{1 i t} \\
& e m p l_{i t}=c_{0}+c_{1} e m p l_{i, t-1}+\ldots+c_{p} e m p l_{i, t-p}+d_{1} s a l_{i, t-1}+\ldots+d_{p} s a l_{i, t-p}+e_{2 i t}
\end{aligned}
$$

and verifying that it is well-specified (no serial correlation in residuals).

- re-estimating the VAR model by adding in one more lag (meaning the maximum order of integration of the series) for each variable in each of the models.

- using the Wald test in order to verify the null hypothesis that the coefficients of the first $p$ lagged values of the EMPL variable are 0 in the SAL equation and vice versa.

Among the appropriate methods to be used to analyze the long-run relationship, Autoregressive Distributed Lag (ARDL) procedure brings at least two important advantages (Ho-Chuan Huang (River) and Chih-Chuan Yeh, 2011): can be applied both for stationary and non-stationary variables and provides long-run and short-run estimates.

We have started from an $\operatorname{ARDL}(\mathrm{p}, \mathrm{q}, \mathrm{r})$ model in which we have included an error correction term:

$$
\Delta s a l_{i t}=a_{i}+\sum_{j=1}^{p-1} b_{i j} \Delta s a l_{i, t-j}+\sum_{j=0}^{q-1} c_{i j} \Delta e m p l_{i, t-j}+\sum_{j=0}^{r-1} d_{i j} \Delta g v a_{i, t-j}+\phi_{i} z_{i, t-1}+e_{i t},
$$

where $\mathrm{Z}_{\mathrm{i}}$, the error correction term, is the series of residuals from the long-run cointegrating regression:

$$
s a l_{i t}=\alpha_{i}+\beta \cdot e^{e m p l} l_{i t}+\gamma \cdot g v a_{i t}+\varepsilon_{1 i t}
$$

The error correction term measures the speed of adjustment towards the longrun equilibrium. If this coefficient is negative and statistic significant that implies that there is a long-run cointegrated relationship between the two variables.

The coefficients $b_{i j}$ refer to the autoregressive coefficients of lag $p$ of the dependent variable measuring time persistence of salaries dynamics. The second category $c_{i j}$ and $d_{i j}$ includes the coefficients of lag $q$ and $\mathrm{r}$ relating the dependent and the independent variables, measuring short-term impact of employment and GVA on salaries.

\section{Results}

\subsection{Descriptive statistics}

In Romania, even though total unemployment rate, of approximately $5 \%$ in 2017, is even smaller than the mean of the European Union countries (around 7.6\%), total employment remains low, of approximately $64 \%$ of the number of working age 
Investigating the Long and Short-Run Salary- Employment Relationship in Romania: A Sectorial Approach Using the ARDL Model

population (from 15 to 64 years). Sectorial distribution of employment shows significant differences in terms of the number of people employed between primary and secondary sectors (agriculture and manufacturing) and the size of other sectors. In 2016, for example more than $42 \%$ of the employed population was involved in agriculture and manufacturing. Twenty years ago the two sectors cumulated almost $64 \%$ of the entire employed population. Box plot graphs draw attention to these differences that have diminished over time once with the significant decrease in the number of total employed population, from 11 million in 1995 to little over 8 million in 2016, caused by demographic or economics transformations. Moreover, for the same year, Kernel density graph points to three groups of sectors of activity function of the number of the employees: agriculture, manufacturing and trade and other sectors (Figure 1).
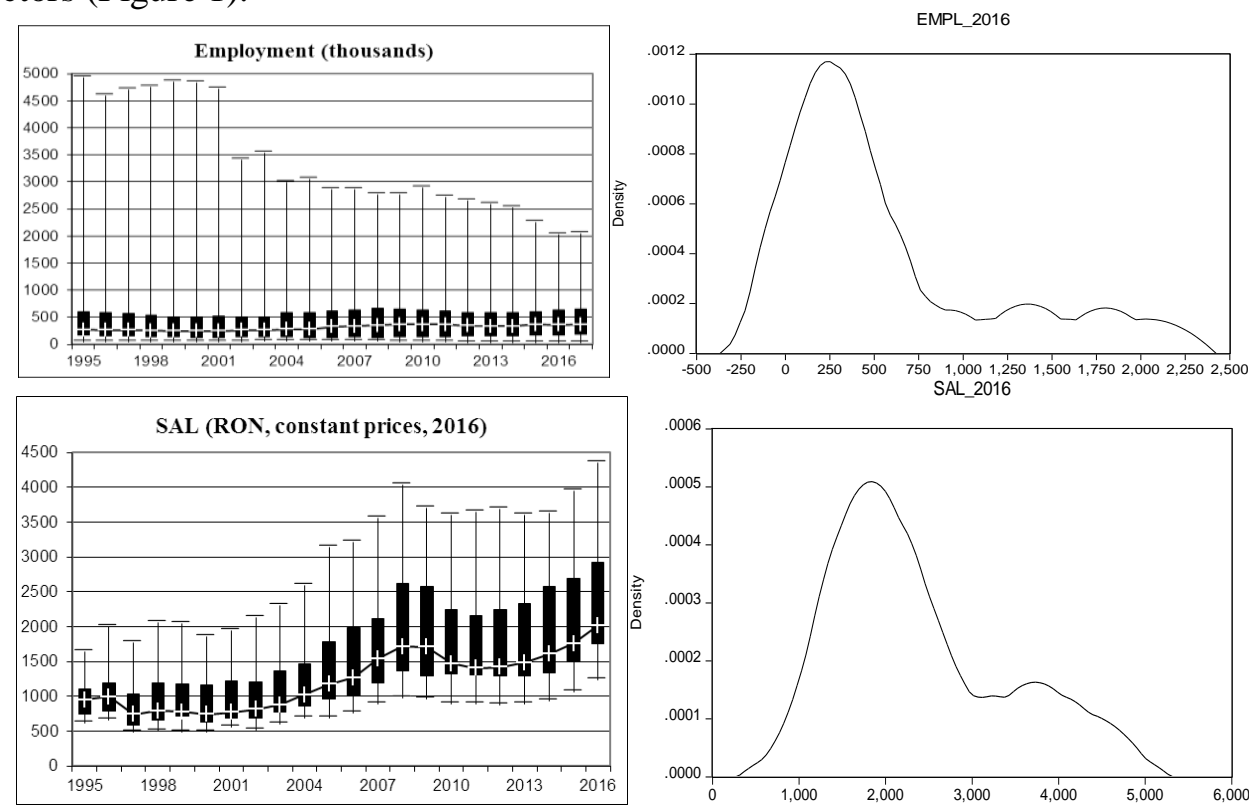

Source: Author own calculation

\section{Figure 1. Box plots and k-density estimates of sectorial employment and salary earnings in Romania}

Salary earnings evolution over time reflects the state of the economy. Thus, median salary earning across economic sectors represented in the box plot graph with 
Gina Cristina Dimian, Erika Marin, Josef Jablonsky

a line, registered a stable increse in the period before the crisis, a reduction after 2008 and a period of recovery starting with 2012. Differences between sectors have substantially increased, reaching in 2016 a gap of 3126 RON between a salary earning of $4358 \mathrm{RON}$ in Information and communication activities and $1232 \mathrm{RON}$ in Accommodation and food service activities. Similar discrepancies are refleted by the interquartile range increase (Figure 1). Moreover, Kernel density graph demonstrates the existence of two categories of sectors in terms of earnings: in most sectors salary earnings were about $2000 \mathrm{RON}$ in 2016, and in another group of sectors salary earnings were between 3,000 and 4,000 RON (Information and communication, Financial and insurance activities, Mining and quarrying, Public administration and defence).

\subsection{Econometric analysis}

\subsubsection{Structural break and integration analysis of the time series}

In order to provide greater accuracy to the econometric analysis of our main variables: employment (EMPL), salary earnings (SAL) and gross value added (GVA) we decided to start with structural break detection in these time series. Even though the time span of 22 years (1995-2016) underlying our research is not too long, it has certainly been marked by events that have influenced the evolution of the above mentioned indicators. The financial crisis that started in 2008-2009 is such an example.

Figure 2 presents the results of the CUSUM of squares tests for the main sectors of activity in Romania in terms of employment (Agriculture, Manufacturing and Trade) and our three variables: employment, salary earnings and GVA. Although the results of the analysis of the remaining 11 sectors were not included in this paper for the sake of concision, they are valid on request.

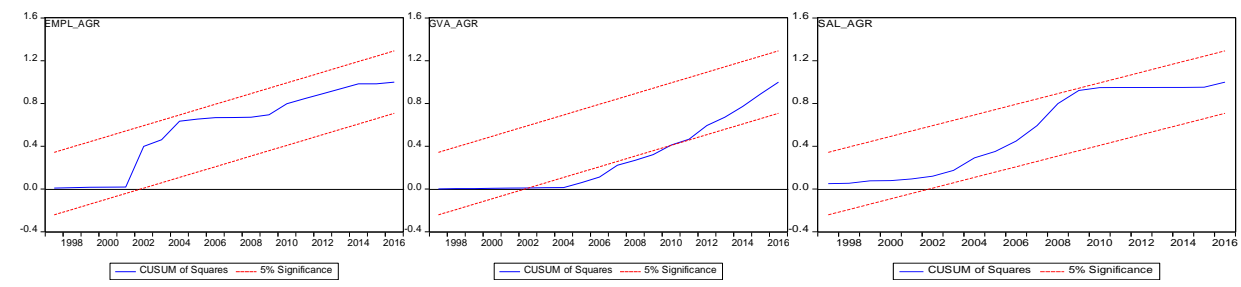


Investigating the Long and Short-Run Salary- Employment Relationship in Romania: A Sectorial Approach Using the ARDL Model

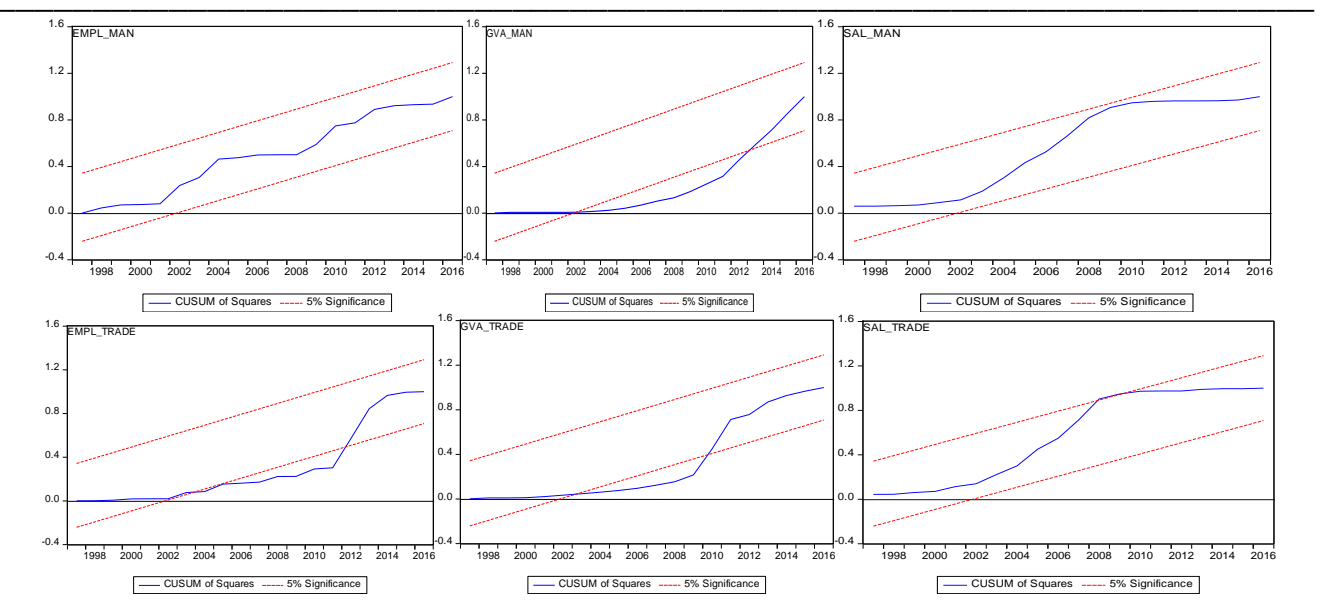

Figure 2. CUSUM of Squares Tests 'results for Agriculture, Manufacturing and Trade

Regarding the first variable analyzed, employment, it seems to have experienced structural changes throughout the period, but the most affected by the financial crisis was the service sector. Agriculture and manufacturing appear to have experienced significant structural changes in 2001. In terms of salary earnings, all sectors show a structural break in 2008-2009, except for agriculture that turns out to be less responsive to economic oscillations. The evolution over time of GVA is, however, similar in all sectors presented in the above graphs, with an expected structural break in the crisis period.

The results of the investigation of structural changes convinced us of the usefulness of testing the stationarity of the time series by means of breakpoint unit root test. For this purpose, we have applied Vogelsang test, which included trend and intercept both in basic specification and in breaking. We have used Innovation Outlier as break type and Dickey-Fuller min-t, as breakpoint selection. The break point unit root tests demonstrate that we are dealing with a mix of stationary and I(1) variables (the results of the Vogelsang test were not included in this paper for the sake of concision, but they are valid on request).

3.2.2. The analysis of stationarity with panel data came to confirm the above mentioned outcomes of the time series investigation. Namely, we have tested the existence of a unit root in each panel data series, based on the relationship expressed in equation (2). First, we have included in test equation only individual intercept and then individual intercept and trend. The results of the second option have been more 
Gina Cristina Dimian, Erika Marin, Josef Jablonsky

conclusive and therefore they have been reported in Table 1. The optimal lag length was chosen by Akaike Information Criterion (AIC).

In terms of the variable, gross value added (GVA), all tests (Breitung t-stat, Im, Pesaran and Shin W-state, ADF - Fisher Chi-square, PP - Fisher Chi-square), except Levin, Lin \& Chu t, confirmed the existence of the unit root and thus the hypothesis of non-stationarity. As regards the main variables, salary earnings (SAL), and employed population (EMPL) the results were divergent (Im, Pesaran and Shin $\mathrm{W}$-stat and ADF - Fisher Chi-square rejected the hypothesis of non-stationarity for EMPL, while Levin, Lin \& Chu t, Breitung t-stat, Im, Pesaran and Shin W-stat, ADF Fisher Chi-square rejected it for $S A L)$.

Table 1. Panel Unit Root Tests

\begin{tabular}{|l|r|r|r|r|r|r|}
\hline \multirow{1}{*}{ Tests } & \multicolumn{2}{|c|}{$\begin{array}{c}\text { Employed } \\
\text { population }\left(\text { empl }_{i t}\right)\end{array}$} & \multicolumn{2}{c|}{$\begin{array}{c}\text { Salary earnings } \\
\left(\mathrm{sal}_{i t}\right)\end{array}$} & \multicolumn{2}{c|}{$\begin{array}{c}\text { Gross value added } \\
\left(g v a_{i t}\right)\end{array}$} \\
\cline { 2 - 7 } & \multicolumn{1}{|c|}{ Level } & $\begin{array}{c}\text { First } \\
\text { difference }\end{array}$ & \multicolumn{1}{c|}{ Level } & \multicolumn{1}{c|}{$\begin{array}{c}\text { First } \\
\text { difference }\end{array}$} & Level & $\begin{array}{c}\text { First } \\
\text { difference }\end{array}$ \\
\hline Levin, Lin \& & -1.205 & -9.102 & -1.421 & -8.503 & -5.821 & -9.690 \\
Chu t* & $(0.114)$ & $(0.000)$ & $(0.078)$ & $(0.000)$ & $(0.000)$ & $(0.000)$ \\
\hline Breitung t-stat & -0.160 & -6.806 & -4.476 & -7.044 & 2.098 & -5.324 \\
& $(0.437)$ & $(0.000)$ & $(0.000)$ & $(0.000)$ & $(0.982)$ & $(0.000)$ \\
\hline Im, Pesaran & & & & & -0.232 & -8.415 \\
and Shin W- & -2.874 & -9.204 & -3.704 & -7.174 & $(0.408)$ & $(0.000)$ \\
stat & $(0.002)$ & $(0.000)$ & $(0.000)$ & $(0.000)$ & & \\
\hline ADF - Fisher & 47.212 & 123.511 & 54.774 & 96.081 & 30.239 & 122.130 \\
Chi-square & $(0.013)$ & $(0.000)$ & $(0.002)$ & $(0.000)$ & $(0.352)$ & $(0.000)$ \\
\hline PP - Fisher & 29.989 & 150.014 & 22.431 & 109.820 & 23.980 & 232.731 \\
Chi-square & $(0.682)$ & $(0.000)$ & $(0.761)$ & $(0.000)$ & $(0.683)$ & $(0.000)$ \\
\hline
\end{tabular}

Note1: Variables are measured in logs; Note 2: Test equation includes individual intercept and trend; Note 3: p-values are reported in parenthesis.

Source: Author own estimations

3.2.3. Taking into account the results of the analysis of stationarity (namely, a mix of stationary variables such as employment, non-stationary variables such GVA and most likely weak stationary variable such as salary earnings), we have investigated panel causality using Toda-Yamamoto procedure, through which Granger causality can be applied to non-stationary series. We have first estimated a VAR model with employment and salary earnings as endogenous variables which included 2 lags for both these variables. Then, we gradually increased the number of lags to 5, 
Investigating the Long and Short-Run Salary- Employment Relationship in Romania: A Sectorial Approach Using the ARDL Model

when we obtained a valid model from the point of view of LM test for residual autocorrelation. In this valid model we have included as exogenous variables employment and salary earnings with lag 6 .

The results of the WALD tests applied to this last VAR model have shown that the significant influence (at a 5\% level of significance) is manifested from employment to salaries ( $\mathrm{Prob}=0.0294)$. The inverse influence is significant only at a $10 \%$ level of significance $(\operatorname{Prob}=0.0689)$.

The outcomes of both stationarity analysis and Toda-Yamamoto causality determined as to select an ARDL model for estimating the relationship between employment and salary earnings, with this last variable as regressand and employment and GVA as regressors.

The estimators have been obtained by Pooled Mean Group (PMG) procedure. The method has been chosen for at least three reasons: can be used for stationary and non-stationary variables, provides long and short-term estimates and cross-section short-run coefficients (Huang and Yeh, 2011). Lags length was chosen $(3,1,1)$ according to AIC criterion.

Table 2 contains the results for the whole Romanian economy and table 3 exhibits the short run coefficients for each of the 14 economic sectors. Thus, error correction coefficient is negative and statistically significant for the whole economy (0.114), which can be interpreted as evidence of long-run co-integration relationship between employment and salary earnings. Namely, approximately $11 \%$ of any disequilibrium between salary earnings and employment is corrected within 1 year. The results at sectorial level are more diverse. The long-term relationship seems not to be available for sectors like: Agriculture, forestry and fishing, Mining and quarrying and Electricity, gas, steam and air conditioning supply (the error correction coefficients are positive), Education and Human health and social work activities (the error correction coefficients are not significant).

Table 2. Panel long and short-run estimation for Romanian economy in the period 1995-2016

\begin{tabular}{|l|r|r|}
\hline Dependent variable: $\Delta s a l_{i t}$ & Coefficients & \multicolumn{1}{|c|}{$\begin{array}{c}\text { Standard } \\
\text { Error }\end{array}$} \\
\hline$e m p l_{i t}$ & $2.174 * * *$ & 0.333 \\
\hline$g v a_{i t}$ & $0.114 * * *$ & 0.043 \\
\hline Error correction coefficient $\left(\phi_{i}\right)$ & $-0.114 * *$ & 0.044 \\
\hline
\end{tabular}


Gina Cristina Dimian, Erika Marin, Josef Jablonsky

\begin{tabular}{|l|r|r|}
\hline$\Delta s a l_{i t}(-1)$ & $-0.157 * *$ & 0.035 \\
\hline$\Delta s a l_{i t}(-2)$ & $-0.099 * * *$ & 0.041 \\
\hline$\Delta e m p l_{i t}$ & $-0.332 * * *$ & 0.097 \\
\hline$\Delta g v a_{i t}$ & $0.059 * *$ & 0.028 \\
\hline Dummy_2009 & $-0.245^{* * *}$ & 0.035 \\
\hline $\mathrm{C}$ & $-0.893 * *$ & 0.395 \\
\hline Trend & $0.021^{* * *}$ & 0.004 \\
\hline Observations & 266 & \\
\hline
\end{tabular}

Note1: Model selection method: Akaike criterion (AIC); Note2: Selected Model:

$\operatorname{ARDL}(3,1,1)$; Note3: All variables are measured in logs.

Source: Author own calculation

The long-run coefficient that relates the salary earnings and employment is significant and positive $(2,174)$ indicating a direct relationship between salary earnings and employment in the long-term. More precisely, increasing employment by $1 \%$ leads to salary earnings increase by around $2 \%$. As expected, positive and significant is also the long run relationship between salary earnings and gross value added. At the same time, the short-run coefficient which estimates the relationship between the main variables salary earnings and employment is significant but negative $(-0.332)$, while the coefficient that relates the salary earnings and GVA is significant and positive (0.059).

On the short run, at sectors of activity levels, the strongest negative influence of employment on salary earnings was recorded by: Information and communication and Manufacturing. There have also been certain sectors for which the relationship real salary earnings-employment has been direct: Agriculture, forestry and fishing, Accommodation and food service activities and Construction. But in this sector' case the relationship seems not to be significant. As for the influence of GVA growth on salary earnings at sectors of activity level on the short run, we can conclude that, at least for the period under review, economic advance has not automatically involved increasing the salary earnings in sectors like: Construction and Wholesale and retail trade; repair of motor vehicles and motorcycles (the coefficients that relate these two variables are significant but negative on short run).

Regarding the coefficient of the Dummy variable, included in the analysis to capture the crisis period (which started in 2009), it proved to be significant and negative both at the ensemble of the economy and sectors of activity level. 
Investigating the Long and Short-Run Salary- Employment Relationship in Romania: A Sectorial Approach Using the ARDL Model

Table 3. Panel short run estimation for 14 economic sectors and the period 1995 2016

\begin{tabular}{|c|c|c|c|c|c|c|c|}
\hline $\begin{array}{c}\text { Model } \\
\text { dependent } \\
\text { variable: } \\
\Delta s a l_{i t}\end{array}$ & $\left(\phi_{i}\right)$ & $\Delta s a l_{i, t-1}$ & $\Delta s a l_{i, t-2}$ & $\Delta e m p l_{i t}$ & $\Delta g v a_{i t}$ & DUM & C \\
\hline AGR & $\begin{array}{r}0.156 \\
0.004 * *\end{array}$ & $\begin{array}{r}-0.024 \\
0.012\end{array}$ & $\begin{array}{r}-0.198 \\
0.010^{* *}\end{array}$ & $\begin{array}{r}0.093 \\
0.014^{* *}\end{array}$ & $\begin{array}{r}0.155 \\
0.003 * *\end{array}$ & $\begin{array}{c}-0.198 \\
0.002 * *\end{array}$ & $\begin{array}{c}1.953 \\
0.682 *\end{array}$ \\
\hline MIN & $\begin{array}{r}0.112 \\
0.003 * * \\
\end{array}$ & $\begin{array}{r}-0.294 \\
0.007 * * \\
\end{array}$ & $\begin{array}{r}0.017 \\
0.05^{* *} \\
\end{array}$ & $\begin{array}{r}-0.084 \\
0.014 * *\end{array}$ & $\begin{array}{r}0.043 \\
0.000^{* * *}\end{array}$ & $\begin{array}{r}-0.270 \\
0.000^{* *}\end{array}$ & $\begin{array}{r}0.525 \\
0.106^{* *} \\
\end{array}$ \\
\hline MAN & $\begin{array}{r}-0.352 \\
0.004 * * \\
\end{array}$ & $\begin{array}{l}0.001 \\
0.007 \\
\end{array}$ & $\begin{array}{r}-0.219 \\
0.006 * * \\
\end{array}$ & $\begin{array}{r}-0.831 \\
0.026^{* *} \\
\end{array}$ & $\begin{array}{r}0.150 \\
0.003 * * \\
\end{array}$ & $\begin{array}{r}-0.010 \\
0.001 * * \\
\end{array}$ & $\begin{array}{r}-4.215 \\
0.779 * * \\
\end{array}$ \\
\hline ELEC & $\begin{array}{l}0.040 \\
0.018 \\
\end{array}$ & $\begin{array}{r}-0.206 \\
0.048 * * \\
\end{array}$ & $\begin{array}{r}0.192 \\
0.029 * *\end{array}$ & $\begin{array}{r}-0.348 \\
0.071 * *\end{array}$ & $\begin{array}{r}0.077 \\
0.010^{* *}\end{array}$ & $\begin{array}{r}-0.266 \\
0.005^{* *}\end{array}$ & $\begin{array}{r}0.082 \\
0.610^{* *}\end{array}$ \\
\hline CONS & $\begin{array}{r}-0.153 \\
0.015^{* *} \\
\end{array}$ & $\begin{array}{r}-0.279 \\
0.012 * * \\
\end{array}$ & $\begin{array}{r}-0.187 \\
0.013 * *\end{array}$ & $\begin{array}{l}0.007 \\
0.070 \\
\end{array}$ & $\begin{array}{r}-0.034 \\
0.007 * *\end{array}$ & $\begin{array}{r}-0.292 \\
0.006 \text { ** }\end{array}$ & $\begin{array}{r}-1.377 \\
0.924 \\
\end{array}$ \\
\hline TRADE & $\begin{array}{r}-0.213 \\
0.010^{* *}\end{array}$ & $\begin{array}{r}-0.302 \\
0.012 * * \\
\end{array}$ & $\begin{array}{l}-0.022 \\
0.008^{*}\end{array}$ & $\begin{array}{r}-0.637 \\
0.089^{* *}\end{array}$ & $\begin{array}{r}-0.033 \\
0.001 * *\end{array}$ & $\begin{array}{r}-0.261 \\
0.003^{* *}\end{array}$ & $\begin{array}{r}-2.179 \\
1.173 \\
\end{array}$ \\
\hline TRANS & $\begin{array}{r}-0.208 \\
0.007 * *\end{array}$ & $\begin{array}{r}0.105 \\
0.006^{* *}\end{array}$ & $\begin{array}{r}0.040 \\
0.004^{* *}\end{array}$ & $\begin{array}{r}-0.577 \\
0.057 * *\end{array}$ & $\begin{array}{r}0.017 \\
0.002^{* *}\end{array}$ & $\begin{array}{r}-0.159 \\
0.001 * *\end{array}$ & $\begin{array}{r}-1.603 \\
0.500 * *\end{array}$ \\
\hline ACCOM & $\begin{array}{r}-0.174 \\
0.007 * * \\
\end{array}$ & $\begin{array}{r}-0.247 \\
0.015^{* *} \\
\end{array}$ & $\begin{array}{l}0.004 \\
0.011 \\
\end{array}$ & $\begin{array}{r}0.316 \\
0.026^{* *} \\
\end{array}$ & $\begin{array}{r}0.017 \\
0.002 * * \\
\end{array}$ & $\begin{array}{r}-0.313 \\
0.003 * * \\
\end{array}$ & $\begin{array}{c}-0.965 \\
0.221 * *\end{array}$ \\
\hline INFO & $\begin{array}{r}-0.244 \\
0.014 * *\end{array}$ & $\begin{array}{r}-0.169 \\
0.035^{* *}\end{array}$ & $\begin{array}{r}-0.277 \\
0.029 * *\end{array}$ & $\begin{array}{r}-0.875 \\
0.068^{* *}\end{array}$ & $\begin{array}{r}-0.179 \\
0.011^{* *}\end{array}$ & $\begin{array}{r}0.037 \\
0.005^{* *}\end{array}$ & $\begin{array}{l}-0.825 \\
0.277^{*}\end{array}$ \\
\hline FIN & $\begin{array}{r}-0.030 \\
0.007 * * \\
\end{array}$ & $\begin{array}{r}-0.232 \\
0.036 * * \\
\end{array}$ & $\begin{array}{r}-0.115 \\
0.025^{* * *} \\
\end{array}$ & $\begin{array}{r}-0.164 \\
0.034 * * \\
\end{array}$ & $\begin{array}{r}0.025 \\
0.006^{* *} \\
\end{array}$ & $\begin{array}{r}-0.222 \\
0.004 * * \\
\end{array}$ & $\begin{array}{r}-0.124 \\
0.061 \\
\end{array}$ \\
\hline REAL & $\begin{array}{r}-0.054 \\
0.001 * * \\
\end{array}$ & $\begin{array}{r}-0.302 \\
0.032 * * \\
\end{array}$ & $\begin{array}{r}-0.281 \\
0.020^{* *}\end{array}$ & $\begin{array}{r}-0.071 \\
0.008^{* *}\end{array}$ & $\begin{array}{r}0.222 \\
0.009^{* * *}\end{array}$ & $\begin{array}{r}-0.360 \\
0.005^{* *}\end{array}$ & $\begin{array}{r}-0.493 \\
0.025 * *\end{array}$ \\
\hline ADM & $\begin{array}{r}-0.411 \\
0.017 * * \\
\end{array}$ & $\begin{array}{r}-0.010 \\
0.021 \\
\end{array}$ & $\begin{array}{l}0.016 \\
0.018 \\
\end{array}$ & $\begin{array}{r}-0.343 \\
0.046^{* *}\end{array}$ & $\begin{array}{r}0.134 \\
0.008^{* *}\end{array}$ & $\begin{array}{r}-0.317 \\
0.007 * *\end{array}$ & $\begin{array}{l}-2.496 \\
0.848^{*}\end{array}$ \\
\hline EDU & $\begin{array}{r}-0.014 \\
0.038 \\
\end{array}$ & $\begin{array}{r}-0.146 \\
0.030 * * \\
\end{array}$ & $\begin{array}{r}-0.024 \\
0.027\end{array}$ & $\begin{array}{r}-0.401 \\
0.248 \\
\end{array}$ & $\begin{array}{r}0.195 \\
0.024 * * \\
\end{array}$ & $\begin{array}{r}-0.392 \\
0.011 * *\end{array}$ & $\begin{array}{r}-0.331 \\
1.788\end{array}$ \\
\hline HEALTH & $\begin{array}{r}-0.050 \\
0.046\end{array}$ & $\begin{array}{c}-0.099 \\
0.040^{*}\end{array}$ & $\begin{array}{r}-0.329 \\
0.024 * *\end{array}$ & $\begin{array}{r}-0.726 \\
0.218^{* *}\end{array}$ & $\begin{array}{r}0.040 \\
0.005^{* *}\end{array}$ & $\begin{array}{r}-0.405 \\
0.010^{* *}\end{array}$ & $\begin{array}{r}-0.451 \\
1.768\end{array}$ \\
\hline
\end{tabular}

$* *$ significant at $1 \%$ level of significance; * significant at $5 \%$ level of significance; Note1: Model selection method: Akaike criterion (AIC); Note2: Selected Model: $\operatorname{ARDL}(3,1,1)$; Note3: All variables are measured in logs.

Source: Author own estimations 
Gina Cristina Dimian, Erika Marin, Josef Jablonsky

\section{Conclusions}

The objective of this paper was to study the relationship between real salary earnings and employment, focusing on the specificity of Romanian sectors of activity. Its implementation has involved in a first step studying the dynamics of the two variables: total employment (domestic concept) and net real monthly salary earnings. In a second step, the analysis of the relationship between the two indicators implied: time series structural break and integration analysis, panel integration examination and panel causality. The investigation covered the period 1995-2016 and 14 sectors.

The research topic is interesting not only from the perspective of verifying the validity of economic theory, but also in practical terms of the macroeconomic policies that can be promoted to boost employment and reduce unemployment.

In this context, descriptive analysis has revealed some interesting aspects about the time evolution of the two indicators. Both in the case of total employment and of salary earnings one can notice a phenomenon of polarization towards certain sectors. Thus, even in 2016 the highest number of people was employed in agriculture and manufacturing sectors, more than $42 \%$ of the total number. Regarding wages, in the same year, two groups of sectors could be distinguished: those with low salaries (around 2,000 RON) and those with average salaries (around 4,000 RON), with an obvious polarization towards low wages.

Studying the link between the two variables has begun with assessing the stationarity of the statistical series and continued, given that we have obtained a mix of stationary and I(1) integrated variables with Granger causality by means of TodaYamamoto procedure. Thus, one of the approaches that can be used in this case, ARDL model has been chosen. It provides among the advantages the ability to be applied to the series that are or not stationary and the estimators offer the possibility to evaluate both the long and the short-term relationship between variables (Huang and Yeh, 2013).

The results of the econometric analysis have proved that there is a long-term relationship between real salary earnings and employment, the error correction coefficient is negative and significant. Also, it seems that in the long-run this relation is direct, while in the short-term it is inverse. The variable GVA, introduced into model in order to quantify the dynamics of the business cycle turned to have a significant positive influence at the entire economy level.

Another advantage of applying ARDL model it is represented by the possibility to obtain short-term coefficients for each of the sectors analysed. In that sense, the results demonstrated that short-term relationship real salary earningsemployment is also positive for some sectors like: Agriculture, forestry and fishing, Accommodation and food service activities and Construction. But in this sector' case the relationship seems not to be significant. The highest and significant negative 
Investigating the Long and Short-Run Salary- Employment Relationship in Romania: A Sectorial Approach Using the ARDL Model

coefficients were obtained for the following sectors: Information and communication and Manufacturing.

The results of the real salary earnings-employment relationship investigation seem to suggest that, at least on long-run and for a developing economy as Romania, there is a direct relationship between employment and salary earnings. Short-term relationship between the two variables proved to be negative with a few exceptions.

In conclusion, high wages could be a solution for ensuring high employment in the long-term and vice versa. Moreover, Romania needs to create proper conditions for sustainable higher wages by increasing labour productivity and promoting competitive sectors of activity. One solution could be, for example, the widespread use of renewable energy for ensuring the competitiveness of the Romanian industries, taking into account the high potential of rural areas (Acceleanu et al. 2018). In addition, Romania should focus on improving the business environment with the aim of facilitating the spillover effects and support from the private sector (Dinu and Marinaş, 2014).

Employment and labour productivity growth could be achieved by investing in education of both young and not so young people, in order to be able to meet future labour market needs (Dimian et al., 2016). Overall competitiveness of the Romania's economy is a condition to be able to face current uncertainties in international markets and even a precondition for deeper European integration because, otherwise, as Mare and Litan (2012, p. 37) pointed, "labour market and investments flows will be the most affected in a negative way".

\section{REFERENCES}

[1] Aceleanu, M.I., Serban, A.C., Tirca, D.M., Badea, L. (2018), The Rural Sustainable Development through Renewable Energy. The Case of Romania; Technological and Economic Development of Economy, vol. 24, no. 4, pp. 1408-1434; [2] Arpegis, N., Theodosiou, I. (2008), The Employment-Wage Relationship: Was Keynes Right after all?; American Review of Political Economy, vol. 6, no. 1, pp. 40-50; [3] Bakker, B.B. (2015), Employment and the Great Recession: The Role of Real Wages; IMF Working Papers, WP/15/229;

[4] Christl, M., Köppl-Turyna, M., Kucsera, D. (2017), Revisiting the Employment Effects of Minimum Wages in Europe; German Economic Review;

[5] Dias, D. A., Marques, C. R., Martins, F. (2013), Wage Rigidity and Employment Adjustment at the Firm Level: Evidence from survey data; Labour Economics, vol. 23(C), pp. 40-49;

[6] Dimian, G.C., Ileanu, B., Aceleanu, M. (2016), Aging and Economic Competitiveness in the Core of "North Euro-zone"; Inzinerine Ekonomika, Engineering Economics, vol. 27, no. 3, pp. 253-263; 
Gina Cristina Dimian, Erika Marin, Josef Jablonsky

[7] Dinu, M., Marinas, M-C. (2014), Testing the Impact of the Fiscal Policy with the SVAR Model in Seven CEE Economies; Economic Computation and Economic

Cybernetics Studies and Research, vol. 1, pp. 23-49;

[8] Geary, P. T., Kennan, J. (1982), The Employment-real Wage Relationship: An

International Study; Journal of Political Economy, vol. 90, no. 4, pp. 854-871;

[9] Huang (River), H-C. and Yeh, C-C. (2013), Okun's Law in Panels of Countries

and States; Applied Economics, vol. 35, pp. 191-199;

[10] Mare, C., Litan, C. (2012), Perspectives on Euro Introduction in the Romanian

Economy; Baltic Journal of Economics, vol. 12, no. 1, pp. 23-40;

[11] Mehra, Y. (1982), Real Wages and Employment: Evidence from Disaggregated

Data; Eastern Economic Journal, vol. 8, no. 3, pp. 191-196;

[12] Minjina, D.I., Brezeanu, P., Huidumac, C. (2010), Selecting the Group of

Comparable Firms for Valuation by Multiples on Bucharest Stock Exchange;

Economic Computation and Economic Cybernetics Studies and Research, Vol. 44, no. 1,

pp: 183-200;

[13] Morar-Triandafil, C., Brezeanu, P., Huidumac, C. Morar-Triandafil, A. (2011),

The Drivers of the Cee Exchange Rate Volatility - Empirical Perspective in the Context of the Recent Financial Crisis; Romanian Journal of Economic Forecasting, vol.14, no.1, pp. 212-229.

[14] Nickell, S.J., Symons, J. (1990), The Real Wage-Employment Relationship in the United States; Journal of Labor Economics, Part 1, vol. 8, no. 1, pp. 1-15;

[15] Parguez, A. (2008), Money Creation, Employment and Economic Stability: The

Monetary Theory of Unemployment and Inflation; Panoeconomicus, vol. 55, no. 1, pp.

39-67;

[16] Pehkonen, J. (1991), Real Wages-Employment Relationship in Finnish

Manufacturing: A VAR Approach; Applied Economics, vol. 23, no. 10, pp. 1559-1568;

[17] Perron, P. (1989), The Great Crash, the Oil Price Shock, and the Unit Root

Hypothesis; Econometrica, vol. 57, pp. 1361-1401;

[18] Suciu, M.C., Florea C.A. (2017), An Empirical Study on the Migration among

Young Skilled and Creative People; Amfiteatru Economic, vol. 19, no. 46, pp. 727-741;

[19] Suedekum, J., Blien, U. (2004), Wages and Employment Growth: Disaggregated

Evidence for West Germany, IZA Discussion Paper 1128, Bonn;

[20] Tatoğlu, F.Y. (2011), The Long and Short Run Effects between Unemployment

and Economic Growth in Europe; Dogus Universitesi Dergisi, vol. 12, no. 1, pp. 99-113;

[21] Vogelsang, T. J.; Perron P. (1998), Additional Tests for a Unit Root Allowing for a

Break in the Trend Function at an Unknown Time; International Economic Review, vol. 39, pp. 1073-1100;

[22] Zaman, G., Goschin, Z. (2014); Economic Crisis and Wage Divergence: Empirical Evidence from Romania; Prague Economic Papers, vol. 23, no. 4, pp.493-513. 